\title{
Growth rates and starvation survival of three species of the pallium-feeding, thecate dinoflagellate genus Protoperidinium
}

\author{
Susanne Menden-Deuer ${ }^{1,2, *}$, Evelyn J. Lessard ${ }^{1}{ }^{1}$ Jessi Satterberg $^{1,3}$, \\ Daniel Grünbaum ${ }^{1}$ \\ ${ }^{1}$ School of Oceanography, University of Washington, Box 357940, Seattle, Washington 98195, USA \\ ${ }^{2}$ Present address: Western Washington University, Shannon Point Marine Center, 1900 Shannnon Point Road, Anacortes, \\ Washington 98225, USA \\ ${ }^{3}$ Present address: Department of Civil and Environmental Engineering, University of Washington, Box 352700, Seattle, \\ Washington 98195, USA
}

\begin{abstract}
We measured growth rates and starvation survival capacity of 3 thecate heterotrophic dinoflagellate species (Protoperidinium conicum, P. depressum, P. excentricum; Peridiniacea: Dinophyceae), isolated from surface waters in Puget Sound, Washington, USA. Feeding on the diatom Ditylum brightwellii, the 3 species achieved maximum specific growth rates of $1.13,0.21$ and $0.33 \mathrm{~d}^{-1}$ respectively. Maximum growth rates were observed at prey concentrations between 50 and $280 \mu \mathrm{g} C$ $\mathrm{l}^{-1}$. Prey concentrations $<20 \mu \mathrm{g} \mathrm{C}^{-1}$ supported only negative or low growth rates. Predators survived in the presence of 11 phylogenetically diverse phytoplankton species for several days, but only the diatom $D$. brightwellii supported measurable predator growth. Grazing rates of up to $6 \mu \mathrm{C} \mathrm{C} \mathrm{l}^{-1}(22 \mathrm{D}$. brightwellii) Protoperidinium ${ }^{-1} \mathrm{~d}^{-1}$ were calculated from limited data. All species were able to starve for extended periods; $P$. depressum survived up to $71 \mathrm{~d}$ at diatom prey concentrations $<1 \mu \mathrm{g} \mathrm{Cl^{-1 }}$. This extended starvation survival provides Protoperidinium species with a distinct advantage when prey availability is heterogeneous in time or space. Our results suggest that resistance to starvation could affect Protoperidinium's energy allocation and could help explain previously observed dominance of Protoperidinium species in wintertime plankton communities despite low phytoplankton-prey concentrations. The viability of Protoperidinium species in the absence of prey has important implications for their function as both predators of phytoplankton and prey for zooplankton.
\end{abstract}

KEY WORDS: Protoperidinium - Dinoflagellate $\cdot$ Starvation · Growth rate $\cdot$ Heterotrophic protists · Microzooplankton $\cdot$ Food web

Resale or republication not permitted without written consent of the publisher

\section{INTRODUCTION}

Research over the past 2 decades has shown that heterotrophic protists (i.e. microzooplankton) are significant grazers of bacterial and phytoplankton biomass, contribute to the cycling of organic matter and nutrients, and serve as important trophic links in marine microbial food webs (e.g. Smetacek 1981, Sherr \& Sherr 1994, Landry et al. 2000). The significance of heterotrophic protists can largely be attributed to the fact that unicellular organisms can grow rapidly, on the order of 1 division $\mathrm{d}^{-1}$. Heterotrophic protists act both as predators of phytoplankton and as prey for zooplankton. The population dynamics of these organisms therefore can have far-reaching effects on the structure and function of planktonic communities and thus the distribution and flux of organic matter and energy in marine microbial food webs.

Quantitative estimates of protistan growth and ingestion rates are essential for assessing population dynamics. The numerical and functional responses of a variety of heterotrophic protists have been empirically determined in laboratory cultures (e.g. Hansen et al. 1997). Many of these measurements have been made 
with relatively abundant prey. In the ocean, however, phytoplankton concentrations fluctuate frequently, in both time and space. Low phytoplankton concentrations may persist for several months of the year, even in areas with regular phytoplankton blooms such as coastal areas of polar and temperate waters. Recent analyses have shown that phytoplankton abundance is spatially heterogeneous, with prey concentrated in patches and thin layers (Cowles et al. 1998, Franks \& Jaffe 2001, McManus et al. 2003). Finally, even if phytoplankton availability were constant and high, the species composition might not include suitable prey for the predators. Many heterotrophic protists show a high degree of selectivity with regard to their prey (e.g. Buskey 1997, Jakobsen \& Hansen 1997, Naustvoll 2000). Thus, the availability of suitable prey at high density is uncertain at best and possibly rare for any given predator species. Consequently, protistan predators may frequently experience low prey or even starvation conditions. However, few studies have thus far quantified growth or mortality rates of protistan predators at very low prey concentrations.

To better understand the quantitative significance of heterotrophic protists during times of low prey abundance, we investigated growth and starvation survival in the cosmopolitan and exclusively heterotrophic dinoflagellate genus Protoperidinium (Peridiniacea: Dinophyceae). Protoperidinium species feed by deploying a pseudopodium, termed the pallium, around the prey cell, dissolving and absorbing the cell content of the prey before retracting the pallium (Jacobson \& Anderson 1986). Oblea, Zygabikodinium and Diplopsalis are the only other dinoflagellate genera known to use this particular feeding mechanism (Jacobson \& Anderson 1986, Strom \& Buskey 1993, Naustvoll 1998). The pallium allows predators to ingest prey much larger than itself, reversing the typical predator:prey size ratio. Protoperidinium species are therefore competing for prey with larger, multicellular organisms such as copepods, rather than with other unicellular predators such as ciliates. When large phytoplankton cells are 'repackaged' in this manner, their biomass is made available to predators with smaller prey size spectra. For example, copepods have been shown to graze upon protists, including Protoperidinium species (Kiørboe et al. 1996, Nejstgaard et al. 1997, Levinsen et al. 2000b). Thus, Protoperidinium species gain some of their significance by simultaneously preying upon dominant primary producers and transferring that biomass to larger organisms. As a result, the genus Protoperidinium has been relatively well studied in recent years and several growth rates have been published (see Table 2). However, these data primarily reflect Protoperidinium spp. growth rates at high prey concentrations. In this study, we quantified the numerical responses of 3 species of the genus Protoperidinium with an emphasis on low prey concentrations. Further, we estimated how long Protoperidinium spp. could survive in the absence of prey. Our goal was to examine the genus's population dynamics and functional role at low prey concentrations.

\section{MATERIALS AND METHODS}

Isolation and cultivation. The heterotrophic dinoflagellates Protoperidinium conicum (Gran) Balech, $P$. depressum (Bailey) Balech and P. excentricum (Paulsen) Balech were isolated from fresh field samples collected from surface waters in Puget Sound, Washington, USA. Taxonomic identification was based on morphology and thecal plate arrangements according to Dodge (1982). Single cells of Protoperidinium spp. were micropipetted into $20 \mathrm{ml}$ culture flasks containing filtered seawater and 1 of 11 potential prey species (Table 1). These cultures were monitored for up to $10 \mathrm{~d}$ for predator survival and growth. Clonal, but not axenic, Protoperidinium cultures were maintained feeding solely on the diatom Ditylum brightwellii (West) Grunow (Strain CCMP 358). D. brightwelli was chosen as the prey species, because it was the only test prey species that supported growth. Prey algae and each Protoperidinium species were cultured at $12^{\circ} \mathrm{C}$ on a $16: 8 \mathrm{~h}$ light:dark cycle in $f / 2$ medium (Guillard 1975) at a salinity of $30 \mathrm{PSU}$. Batches of the diatom prey were grown in $1000 \mathrm{ml}$ polycarbonate bottles at $100 \mu \mathrm{mol}$ photons $\mathrm{m}^{-2} \mathrm{~s}^{-1}$. Cultures of all Protoperidinium species were kept at $30 \mu \mathrm{mol}$ photons $\mathrm{m}^{-2} \mathrm{~s}^{-1}$ on a plankton wheel rotating at $1 \mathrm{rpm}$.

Growth and ingestion experiments. For each Protoperidinium species, 6 polycarbonate bottles $(275 \mathrm{ml})$ were prepared at each of 6 final prey concentrations

Table 1. Protoperidinium spp. Survival (d) in the presence of phylogenetically diverse phytoplankton. Incubation was terminated after $10 \mathrm{~d}$. Growth was observed only in the presence of the diatom Ditylum brightwellii

\begin{tabular}{|llc|}
\hline Species & Class & Survival \\
\hline Micromonas pusilla & Prasinophyceae & 5 \\
Pyraminomonas sp. & Prasinophyceae & 5 \\
Dunaliella tertiolecta & Chlorophyceae & 10 \\
Amphidinium carterae & Dinophyceae & 7 \\
Gymnodinium simplex & Dinophyceae & 9 \\
Prorocentrum micans & Dinophyceae & 10 \\
Rhodomonas lens & Cryptophyceae & 9 \\
Rhodomonas salina & Cryptophyceae & 10 \\
Isochrysis galbana & Prymnesiophyceae & 8 \\
Pavlova lutheri & Prymnesiophyceae & 10 \\
Ditylum brightwellii & Coscinodiscophyceae & 10 \\
\hline
\end{tabular}


ranging from 0 to 2500 cells $\mathrm{ml}^{-1}$, equivalent to 0 to $600 \mu \mathrm{g} \mathrm{C}^{-1}$ in filtered seawater. At each prey concentration, 3 control bottles were set aside to monitor changes in diatom abundance in the absence of predation. The remaining 3 bottles were amended with dinoflagellate stock culture. Initial dinoflagellate concentrations were 0.1 to $1 \mathrm{cell} \mathrm{ml}^{-1}$. These concentrations were chosen because Jeong \& Latz (1994) measured higher growth rates with initial Protoperidinium species concentrations of 1 compared to 7 cells $\mathrm{ml}^{-1}$. The starvation treatment without added prey con-

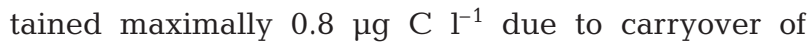
diatoms from the predator inocula. Experimental bottles were maintained at $12^{\circ} \mathrm{C}$ on a plankton wheel rotating at $1 \mathrm{rpm}$ at low light $\left(30 \mu \mathrm{mol}\right.$ photons $\left.\mathrm{m}^{-2} \mathrm{~s}^{-1}\right)$ to minimize diatom growth. Initially, $10 \mathrm{ml}$ aliquots were taken daily and replaced with $10 \mathrm{ml}$ filtered seawater. After 2 to $3 \mathrm{wk}$, sampling frequency was decreased to twice a week. Samples were fixed immediately with glutaraldehyde (1\% final concentration), stained with DAPI and gently ( $5 \mathrm{~mm} \mathrm{Hg}$ ) filtered onto a $2 \mu \mathrm{m}$ black polycarbonate filter (Poretics). Samples from the starvation experiments were inspected live under a dissecting microscope before fixation to ensure cells were alive and actively swimming.

Microscopic analysis. Cell concentrations were determined using a standard epifluorescence microscope (Zeiss) at 200× magnification. For low-concentration samples $(<50$ cells $)$ whole samples were counted, and for high-concentration samples a minimum of 50 cells was counted.

Dinoflagellate and diatom cell sizes were determined from approximately 30 preserved cells with an inverted microscope (Zeiss) equipped with a digitizer pad and Microbiota software (Roff \& Hopcroft 1986). The average cellular carbon content of the diatom prey Ditylum brightwellii was $230 \mathrm{pg} \mathrm{C} \mathrm{cell}^{-1}$ based on an average cell volume of $5500 \mu^{3}$ (Menden-Deuer \& Lessard 2000). No correction for fixation-induced cell size changes was applied (Menden-Deuer et al. 2001).

Growth and ingestion rate calculations. Growth rates were calculated as the slope of the least-squares regression of abundance data during the longest period of increasing cell density, i.e. the linear portion of the semi-natural log plot of cell concentration vs. time in each flask. Mean and standard deviations were calculated independently for each of the triplicate flasks, at each prey concentration. A minimum of 3 and maximum of 15 time points were used as the basis for the growth rate concentrations. The $4 \%$ dilution due to replacing the sample volume was taken into account in the growth rate calculations. Prey concentration was calculated from the geometric mean prey concentration in each flask during the predator growth interval. Only initial diatom abundance data were available for some Protoperidinium excentricum incubations, and prey concentration was based on initial inoculum concentration. Ingestion rates were calculated using the method described by Frost (1972) and Heinbokel (1978).

\section{RESULTS}

\section{Growth rates}

Specific growth rates for all 3 Protoperidinium species increased with increasing prey concentration up to a maximum prey concentration of $280 \mu \mathrm{g} \mathrm{C} \mathrm{l^{-1 }}$ (Fig. 1). A maximum observed specific growth rate of

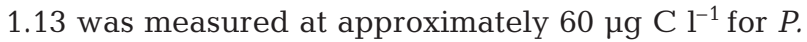
conicum, and 0.21 and $0.33 \mathrm{~d}^{-1}$ at approximately 280 and $250 \mu \mathrm{g} \mathrm{C}^{-1}$ for $P$. depressum and P. excentricum, respectively. Maximum growth rates obtained from fitting the Michaelis-Menten equation to the data resulted in very similar growth rates for $P$. depressum $\left(0.24, \mathrm{r}^{2}=0.81\right)$ and $P$. excentricum $\left(0.29, \mathrm{r}^{2}=0.84\right)$; the data for $P$. conicum did not allow a reasonable fit.

Growth rates measured for Protoperidinium conicum at prey concentrations of approximately $600 \mu \mathrm{g} \mathrm{C} \mathrm{l^{-1 }}$ were notably lower than at lower prey concentrations (Fig. 1a). The reason for this decrease is not clear. However, in our cultures we regularly observed that

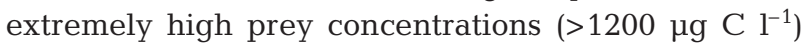
prevent growth and can kill growing Protoperidinium cultures. Specific growth rates for all species changed rapidly with only minimal changes in prey concentration, and our results would have benefited from greater resolution of prey concentration treatments

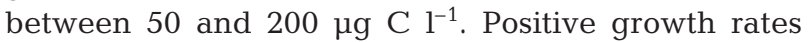
observed at nearly $0 \mu \mathrm{g} \mathrm{C} \mathrm{l}^{-1}$ were probably due to residual growth.

The results of our growth rate calculations were critically dependent upon the time interval considered. To quantify the significance of frequency of samplings on growth rate estimates, we calculated growth rates for hypothetical, fixed time intervals based on the initial and final concentrations only. Depending on the length of the time interval between initial and final samples, calculated growth rates for Protoperidinium depressum could vary by $>100 \%$, irrespective of initial prey concentration (Fig. 2). The variability in growth rate estimates decreased with increasing duration of the experiment for all initial prey concentrations.

\section{Ingestion rates}

In control bottles, there was little or no net growth of diatoms, due to low light levels. Diatom-prey concen- 
tration in the treatments with predators decreased measurably relative to the controls only in incubations where predator abundance had increased substantially (>10 Protoperidinium depressum $\mathrm{ml}^{-1}$; Fig. 3). Thus, we could only calculate ingestion rates for a few incubations for $P$. conicum and $P$. depressum. Despite
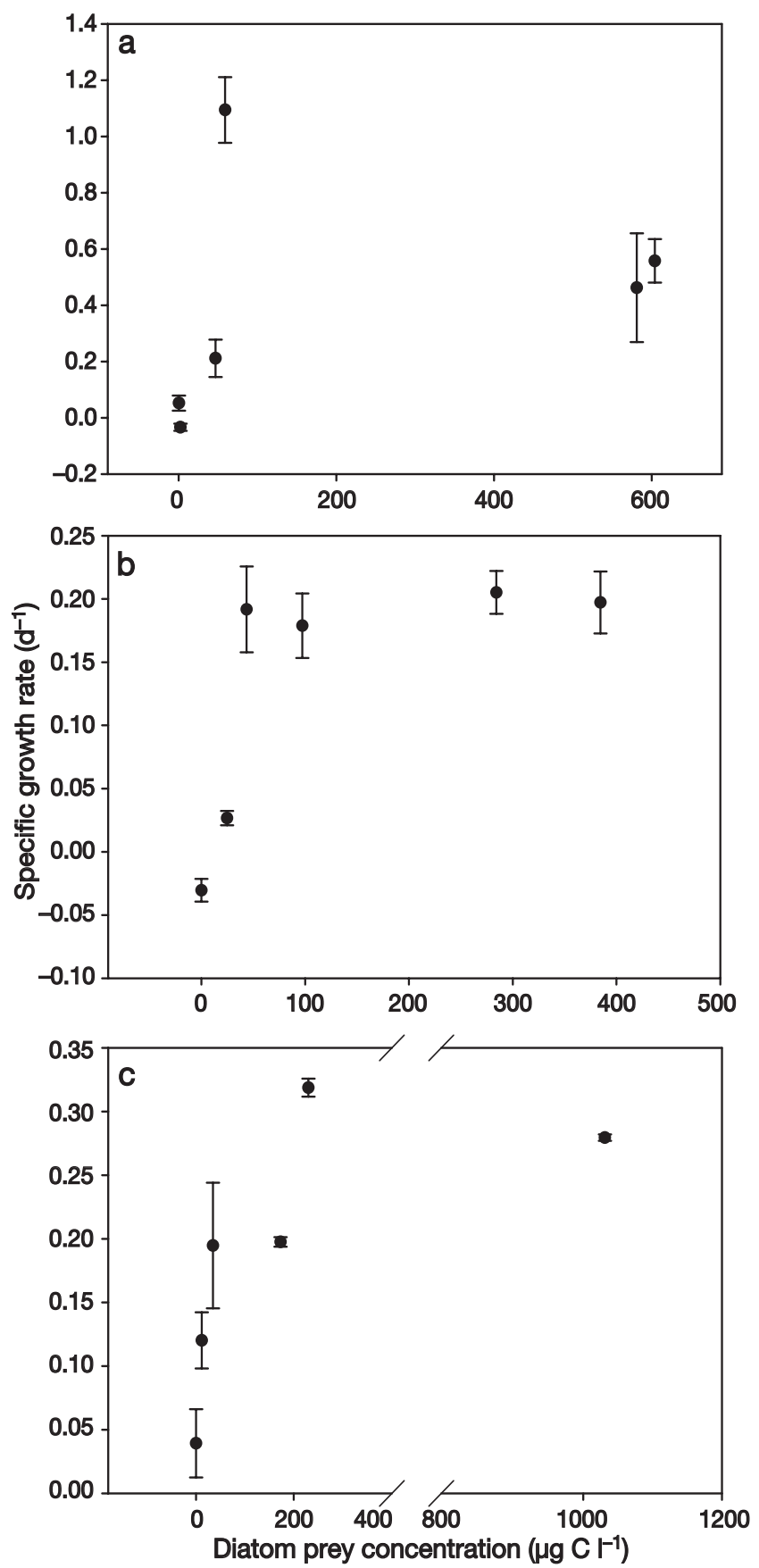

Fig. 1. (a) Protoperidinium conicum, (b) P. depressum, (c) P. excentricum. Specific growth rates as a function of mean diatom prey concentration. Growth rate estimates based on longest continuous exponential phase. Data are means $\pm 1 \mathrm{SD}(\mathrm{n}=3)$

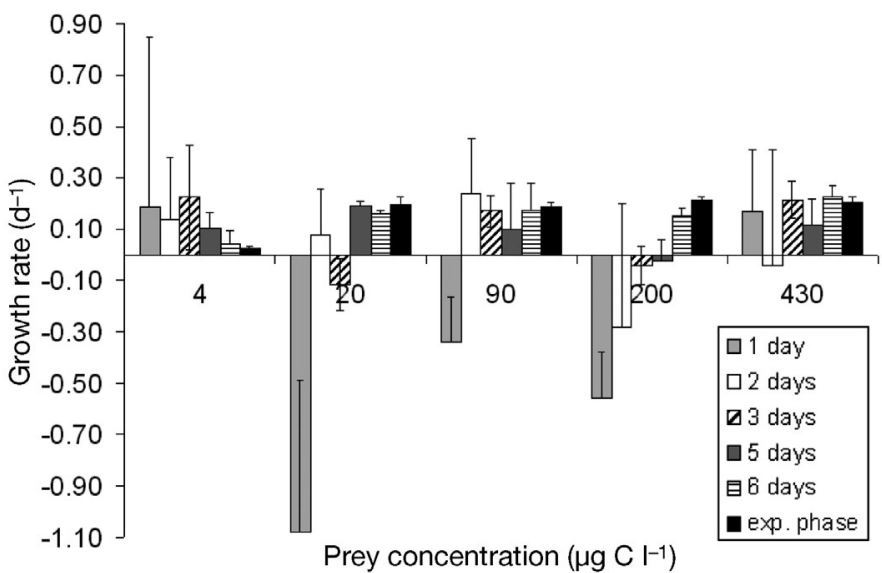

Fig. 2. Protoperidinium depressum. Growth rate estimates calculated from initial and final samples only. Categories represented by initial prey concentration. Actual growth rate determined by fitting regression to daily samples is shown for comparison (exp. phase). Data are means (+1 SD)

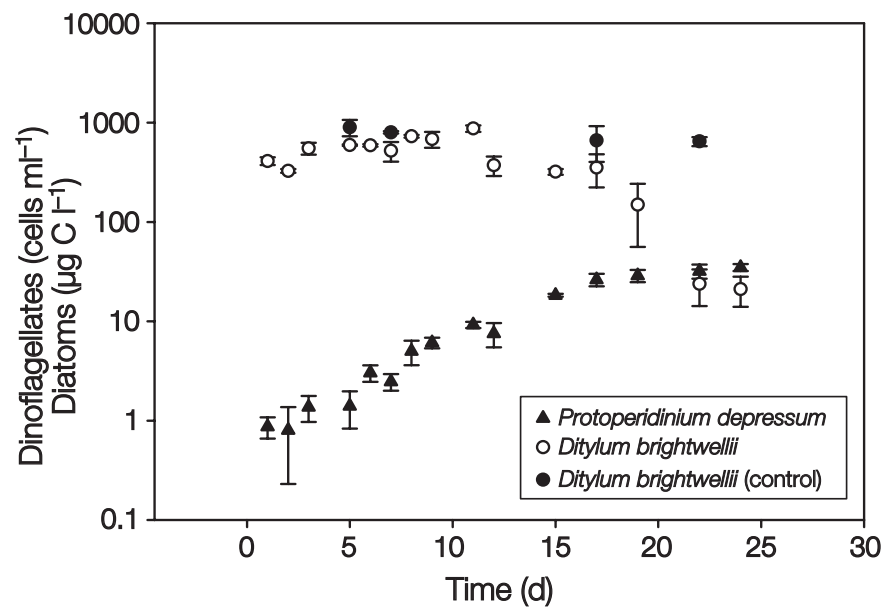

Fig. 3. Protoperidinium depressum and Ditylum brightwellii. Changes in concentrations vs. time

their size difference, both predators had similar ingestion rates. $P$. conicum ingested $22 \pm 1$ and $P$. depressum ingested $15 \pm 3$ D. brightwellii predator ${ }^{-1} \mathrm{~d}^{-1}$ at prey concentrations of 400 and $600 \mu \mathrm{g} \mathrm{Cl}^{-1}$, respectively.

\section{Starvation survival rates}

Protoperidinium spp. were able to survive for a minimum of $5 \mathrm{~d}$ in cultures with 11 phylogenetically diverse phytoplankton species (Table 1). However, growth was observed only with the diatom Ditylum brightwellii. All species of Protoperidinium were able to survive prolonged periods of starvation in cultures with prey concentrations of $<1 \mu \mathrm{g} \mathrm{Cl}^{-1}$ (Fig. 4). At the time the cultures were terminated, the cells were not dead; thus, they may have survived even longer. 


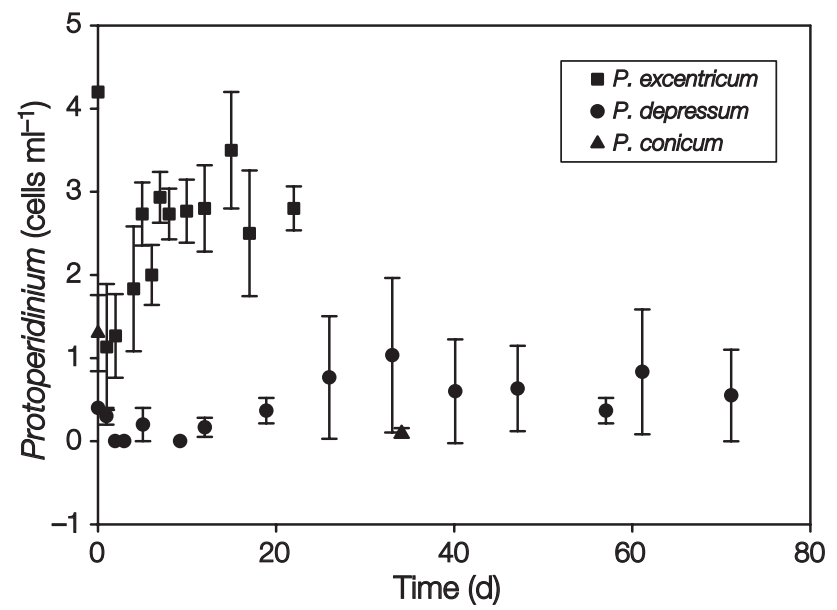

Fig. 4. Protoperidinium spp. Cell concentration vs. time in incubations with extremely low diatom-prey concentrations of $<1 \mu \mathrm{g} \mathrm{Cl}^{-1}$. Note that there are only initial and end-point measurements for $P$. conicum

Observation of live Protoperidinium cells, taken from starving cultures after 1 mo and longer, showed that cells qualitatively appeared much more transparent and swam much slower than well-fed cells. All 3 Protoperidinium species were able to resume growth after starvation upon exposure to $D$. brightwellii prey. Unfortunately, we did not conduct a quantitative analysis to estimate how long, if at all, the lag phase was before predators resumed growth.

\section{DISCUSSION}

Maximum specific growth rates for the 3 Protoperidinium species investigated here ranged from 0.21 to $1.13 \mathrm{~d}^{-1}$. This range corresponds to a population doubling time of 80 to $14 \mathrm{~h}$ for closely related species. The difference of 1 order of magnitude in cell volume amongst species cannot explain the difference in measured growth rates, as the largest and smallest species had similar growth rates. The experiments were conducted under the same culture conditions for all 3 species. Neither the temperature nor the prey species offered were optimized for any of the species, and the difference in growth rate may simply be a reflection of this lack of optimization.

Hansen et al. (1997) established a predictive relationship between dinoflagellate size and growth rate. The growth rates for Protoperidinium depressum and $P$. excentricum measured here correspond well with those predicted by Hansen et al.'s (1997) relationship. Populations of these 2 species would take more than $2 \mathrm{~d}$ to double in biomass. Olseng et al. (2002) attributed rapid increases in Protoperidinium abundance to advection because growth rates of $>1$ division $\mathrm{d}^{-1}$ were considered highly unlikely. However, the measured maximum growth rate for $P$. conicum was more than twice the rate predicted from Hansen et al.'s (1997) regression, and was greater than most reported growth rates for the genus Protoperidinium (Table 2). The importance of experimental conditions such as temperature and prey species to measured growth rates needs to be investigated in greater detail to determine whether $P$. conicum intrinsically grows faster than other dinoflagellate species or whether the particular experimental conditions favored higher growth rates for P. conicum.

Sampling frequency and duration of the experiment were key factors affecting growth rate estimates. With the exception of the highest prey concentrations, growth was not continuous during the incubation; thus, initial and final sampling alone would not have been adequate. Our analysis of growth rate calculations showed that estimates based only on initial and final samples would have resulted in significant differences in estimates of the specific growth rate, because initial decreases in Protoperidinium cell abundance are not measured and duration of lag and onset of stationary phases are unknown.

While rapid growth was only observed in Protoperidinium conicum, all species sustained continuous periods of growth for up to $2 \mathrm{wk}$ at prey concentrations $>280 \mu \mathrm{g} \mathrm{Cl}^{-1}$. The variability in measured growth rates shows that some Protoperidinium species can achieve high growth rates over short time periods, and all can sustain lower growth rates for periods of several days. Therefore, depending on prey concentration, these thecate heterotrophs can undergo rapid or gradual changes in population size and subsequently have

Table 2. Protoperidinium species. Maximum specific growth rates $\left(\mathrm{d}^{-1}\right)$

\begin{tabular}{|lrcl|}
\hline Species & Cell volume $\left(\mu \mathrm{m}^{3}\right)$ & Growth rate & Source \\
\hline P. bipes & 1430 & 1.37 & Jeong et al. (2004) \\
P. cf. divergens & 119000 & 0.49 & Jeong \& Latz (1994) \\
P. conicum & 50000 & 1.13 & This study \\
P. crassipes & 204000 & 0.31 & Jeong \& Latz (1994) \\
P. depressum & 278000 & 0.21 & This study \\
P. excentricum & 24000 & 0.33 & This study \\
P. hirobis & 6400 & 1.23 & Jacobson \& Anderson (1993) \\
P. huberi & 39000 & 0.72 & Buskey et al. (1994) \\
P. pallidum & 53000 & 0.28 & Naustvoll (2000) \\
P. pellucidum & 24600 & 0.7 & Buskey (1997) \\
$P$. pellucidum & 29300 & 0.33 & Hansen (1992) \\
P. spiniferum & 47700 & 0.3 & Jacobson \& Anderson (1986) \\
$P$. steinii & 9000 & 0.18 & Naustvoll (2000) \\
\hline
\end{tabular}


immediate or sustained effects on organism abundance and biogeochemical fluxes in marine microbial food webs.

It is noteworthy that at prey concentrations of $<10 \mu \mathrm{g}$ $\mathrm{C}^{-1}$ some positive growth rates were measured for all 3 species. This growth may partially be explained by a post-feeding, residual cell division as observed by Jakobsen \& Hansen (1997). Growth at prey concentrations $<10 \mu \mathrm{g} \mathrm{C} \mathrm{l}^{-1}$ has also been measured in some other dinoflagellate and ciliate species (Jakobsen \& Hansen 1997).

In our experiments, a significant reduction in diatom biomass in treatments with predators relative to the diatom controls was only observed when Protoperidinium spp. concentrations were relatively high (>10 Protoperidinium cells $\mathrm{ml}^{-1}$; Fig. 3). Published coastal abundances of Protoperidinium spp. are usually $<5$ cells ml $^{-1}$ (Lessard 1991, Kjæret et al. 2000, Olseng et al. 2002). Our own laboratory cultures have infrequently reached maximum concentrations of about 140 cells ml ${ }^{-1}$ for $P$. conicum and $P$. excentricum. Protoperidinium spp. are frequently observed in plankton samples and, because of their conspicuous morphology, are easily identified and routinely reported in plankton surveys. It is unlikely that Protoperidinium abundances are greatly underestimated. Nonetheless, high Protoperidinium spp. concentrations of $>100$ cells ml ${ }^{-1}$ have rarely been reported for field samples (Jeong et al. 2004). If our observations apply to natural plankton communities, Protoperidinium spp. would significantly reduce phytoplankton population size only if its abundance was higher than typically observed concentrations.

All 3 Protoperidinium species investigated herein showed a remarkable ability to survive in the absence of prey for extended periods (over 2 mo for 1 species). No cyst or swarmer formation was observed during this period. Growing and recently fed Protoperidinium spp. appeared optically dense and contain lipid vesicles when viewed under a microscope. P. conicum and $P$. depressum cultures occasionally show a bright pink coloring. However, these pigments were not observed before or during the experiments. Over the course of the starvation experiment, we observed increasing transparency in starved cells and disappearance of visible organelles. We suspect that increases in transparency were due to Protoperidinium cells metabolizing their cell content. These observations suggest that, in addition to a reduced metabolism, Protoperidinium species utilize storage reserves to survive famine conditions.

Several studies have previously reported starvation survival in some heterotrophic protist species (Jackson \& Berger 1984, Fenchel 1990, Jeong \& Latz 1994). To our knowledge, the longest survival previously observed was for an athecate dinoflagellate that could starve for $30 \mathrm{~d}$ (Strom 1991). In contrast, many other protistan predators, particularly ciliates, die rapidly, within hours to a few days of starvation (Jackson \& Berger 1984, Fenchel 1990, Jakobsen \& Hansen 1997). The ability to survive extended periods without food should be considered when comparing growth rates amongst different groups of heterotrophic protists. Whilst ciliates may allocate all acquired energy to cell division, we propose that Protoperidinium species convert part of their energy to storage products not immediately measured as growth. Therefore, to assess and compare predator energetics, both growth rate and starvation survival ability must be considered to estimate realized growth rate and growth efficiency.

Given that phytoplankton are rare or absent over significant spatial (e.g. thin layers, McManus et al. 2003) and temporal scales (e.g. winter-time abundance, Levinsen et al. 2000a), it appears likely that phytoplankton predators have evolved survival strategies to cope with low prey abundances. One of these strategies may be to prey upon a diverse cell size spectrum, which is consistent with the observation that dinoflagellates have the largest predator:prey size ratios known for planktonic predators (Hansen et al. 1994). Another possible strategy is to prey upon a wide prey-species spectrum. Jeong (1994) described Protoperidinium cf. divergens preying on copepod eggs and nauplii. An extensive prey-species spectrum would certainly expand the times of year during which suitable prey were available. Protoperidinium cysts can be observed in live samples. However, no cysts were observed in our experiments and we are not aware that cyst formation occurs in response to starvation. Nonetheless, several different strategies in addition to a reduced metabolism and resistance to starvation may be employed as survival mechanisms and thus deserve further attention.

Viability in the absence of prey provides Protoperidinium species and possibly other dinoflagellates with a competitive advantage. Heterotrophic protists that do not possess the ability to survive without prey for even a short time will undergo drastic fluctuations in abundance, including local extinction. In contrast, protists that do survive starvation can seek out patchy prey and may gain numeric dominance not only through growth but also through reduced mortality rates. Levinsen et al. (2000a) reported that Protoperidinium spp. constituted up to $60 \%$ of the winter heterotrophic dinoflagellate biomass in a Greenland bay. The authors could not trace the source of the population, but hypothesized that reduced metabolic rates allowed protists to survive periods with low phytoplankton concentrations. Our results show that Protoperidinium species can indeed survive prolonged 
periods of adverse conditions, and thereby gain numeric dominance in the plankton community.

Thus far, we do not know by what mechanisms Protoperidinium species survive for such long periods. Knowledge of this mechanism, together with estimates of growth rates of starved cultures, after they have been inoculated with prey, will provide a more complete assessment of the role these predators play in marine microbial food webs, particularly as prey to zooplankton during times of low phytoplankton abundance.

Acknowledgements. We thank R. A. Horner for her kind support of this research. H. H. Jakobsen and 3 anonymous reviewers made valuable comments and suggestions, improving this manuscript. This research was funded by NSF grant OCE-9403426 to E.J.L. Support for S.M.-D. was provided by the German Academic Exchange Service (DAAD) and D.G. received support from NOAA Washington SeaGrant Program (NA040AR170032)

\section{LITERATURE CITED}

Buskey EJ (1997) Behavioral components of feeding selectivity of the heterotrophic dinoflagellate Protoperidinium pellucidum. Mar Ecol Prog Ser 153:77-89

Buskey EJ, Coulter CJ, Brown SL (1994) Feeding, growth and bioluminescence of the heterotrophic dinoflagellate Protoperidinium huberi. Mar Biol 121:373-380

Cowles TJ, Desiderio RA, Carr ME (1998) Small-scale planktonic structure: persistence and trophic consequences. Oceanography 11:4-9

Dodge JD (1982) Marine dinoflagellates of the British Isles. Her Majesty's Stationery Office, London

Fenchel T (1990) Adaptive significance of polymorphic life cycles in Protozoa: responses to starvation and refeeding in two species of marine ciliates. J Exp Mar Biol Ecol 136: 159-177

Franks PJS, Jaffe JS (2001) Microscale distributions of phytoplankton: initial results from a two dimensional imaging fluorometer, OSST. Mar Ecol Prog Ser 220:59-72

Frost BW (1972) Effects of size and concentration of food particles on the feeding behavior of the marine planktonic copepod Calanus pacificus. Limnol Oceanogr 17:805-815

Guillard RRL (1975) Culture of phytoplankton for feeding marine invertebrates. In: Smith WL, Chanley MH (eds) Culture of marine invertebrate animals. Plenum Press, New York, p 26-60

Hansen B, Bjørnsen PK, Hansen PJ (1994) The size ratio between planktonic predators and their prey. Limnol Oceanogr 39:395-403

Hansen PJ (1992) Prey size selection, feeding rates and growth dynamics of heterotrophic dinoflagellates with special emphasis on Gyrodinium spirale. Mar Biol 114:327-334

Hansen PJ, Bjørnsen PK, Hansen BW (1997) Zooplankton grazing and growth: scaling within the $2-2000 \mu \mathrm{m}$ body size range. Limnol Oceanogr 42:687-704

Heinbokel JF (1978) Studies on the functional role of tintinnids in the Southern California Bight. 1. Grazing and growth rates in laboratory cultures. Mar Biol 47:177-189

Jackson KM, Berger J (1984) Survival of ciliated protozoa under starvation conditions and at low bacterial levels. Microb Ecol 10:47-59
Jacobson DM, Anderson DM (1986) Thecate heterotrophic dinoflagellates: feeding behavior and mechanism. J Phycol 22:249-258

Jacobson DM, Anderson DM (1993) Growth and grazing rates of Protoperidinium hirobis (Abe), a thecate heterotrophic dinoflagellate. J Plankton Res 15:723-736

Jakobsen HH, Hansen PJ (1997) Prey size selection, grazing and growth response of the small heterotrophic dinoflagellates Gymnodinium sp. and the ciliate Balanion comatum - a comparative study. Mar Ecol Prog Ser 158: $75-86$

Jeong HJ (1994) Predation by the heterotrophic dinoflagellate Protoperidinium cf. divergens on copepod eggs and early naupliar stages. Mar Ecol Prog Ser 114:203-208

Jeong HJ, Latz MI (1994) Growth and grazing rates of the heterotrophic dinoflagellates Protoperidinium spp. on red tide dinoflagellates. Mar Ecol Prog Ser 106:173-185

Jeong HJ, Yoo YD, Kim ST, Kang NS (2004) Feeding by the heterotrophic dinoilagellate Protoperidinium bipes on the diatom Skeletonema costatum. Aquat Microb Ecol 36: 171-179

Kiørboe T, Saiz E, Viitasalo M (1996) Prey switching behavior in the planktonic copepod Acartia tonsa. Mar Ecol Prog Ser 143:65-75

Kjæret AH, Naustvoll LJ, Paasche E (2000) Ecology of the heterotrophic dinoflagellate genus Protoperidinium in the inner Oslofjord (Norway). Sarsia 85:453-460

Landry MR, Constantinou J, Latas M, Brown SL, Bidigare RR, Ondrusek ME (2000) Biological response to iron fertilization in the eastern equatorial Pacific (IronEx II). III. Dynamics of phytoplankton growth and microzooplankton grazing. Mar Ecol Prog Ser 201:57-72

Lessard EJ (1991) The trophic role of heterotrophic dinoflagellates in diverse marine environments. Mar Microb Food Webs 5:49-58

Levinsen H, Nielsen TG, Hansen BW (2000a) Annual succession of marine pelagic protozoans in Disko Bay, West Greenland, with emphasis on wintertime dynamics. Mar Ecol Prog Ser 206:119-134

Levinsen H, Turner JT, Nielsen TG, Hansen BW (2000b) On the trophic coupling between protists and copepods in arctic marine ecosystems. Mar Ecol Prog Ser 204:65-77

McManus MA, Alldredge AL, Barnard AH, Boss E and 21 others (2003) Characteristics, distribution and persistence of thin layers over a 48 hour period. Mar Ecol Prog Ser 261:1-19

Menden-Deuer S, Lessard EJ (2000) Carbon to volume relationships for dinoflagellates, diatoms, and other protist plankton. Limnol Oceanogr 45:569-579

Menden-Deuer S, Satterberg J, Lessard EJ (2001) Effect of preservation on dinoflagellate and diatom cell volume and consequences for carbon biomass predictions. Mar Ecol Prog Ser 222:41-50

Naustvoll LJ (1998) Growth and grazing by the thecate heterotrophic dinoflagellates Diplopsalis lenticula (Diplopsalidaceae, Dinophyceae). Phycologia 37:1-9

Naustvoll LJ (2000) Prey size spectra and food preferences in thecate heterotrophic dinoflagellates. Phycologia 39: 187-198

Nejstgaard JC, Gismervik I, Solberg PT (1997) Feeding and reproduction by Calanus finmarchicus and microzooplankton grazing during mesocosm blooms of diatoms and the coccolithophore Emiliania huxleyi. Mar Ecol Prog Ser 147:197-217

Olseng CD, Naustvoll LJ, Paasche E (2002) Grazing by the heterotrophic dinoflagellates Protoperidinium steinii on a Ceratium bloom. Mar Ecol Prog Ser 225:161-167 
Roff JC, Hopcroft RR (1986) High precision microcomputer based measuring system for ecological research. Can J Fish Aquat Sci 43:2044-2088

Sherr EB, Sherr BF (1994) Bacterivory and herbivory: key roles of phagotrophic protests in pelagic food webs. Microb Ecol 28:223-235

Smetacek V (1981) The annual cycle of protozooplankton in

Editorial responsibility: David A. Caron,

Los Angeles, California, USA the Kiel Bight. Mar Biol 63:1-11

Strom SL (1991) Growth and grazing rates of the herbivorous dinoflagellate Gymnodinium sp. from the open subarctic Pacific Ocean. Mar Ecol Prog Ser 78:103-113

Strom SL, Buskey EJ (1993) Feeding, growth, and behavior of the thecate heterotrophic dinoflagellate Oblea rotunda. Limnol Oceanogr 38:965-977

Submitted: November 9, 2004; Accepted: September 6, 2005 Proofs received from author(s): November 18, 2005 